\title{
STUDI KONTRASTIF KONSTRUKSI INTEROGATIF POLAR BAHASA JEPANG DAN BAHASA INDONESIA
}

\author{
Abdul Gapur, Mulyadi \\ Pos-el: abdul_gapur@students.usu.ac.id \\ Program Studi Linguistik, Universitas Sumatera Utara
}

\begin{abstract}
A bstrak
Penelitian ini membahas tentang konstruksi interogatif polar dalam bahasa Jepang dan bahasa Indonesia. Tujuan penelitian ini untuk mendeskripsikan bentuk, persamaan dan perbedaan, dan kesepadanan konstruksi interogatif dalam bahasa Indonesia dan bahasaJepang. Sumber data adalah literatur yang berkaitan tentang konstruksi interogatif dan buku tatabahasa Indonesia dan bahasa Jepang. Pengumpulan data dengan teknik catat. A nalisis data menggunakan analisis kontrastif dengan pendekatan strukturalis. Hasil penelitian ditemukan bahwa kontrastif interogatif polar bahasa epang dan bahasa Indonesia terbentuk dari 1) penggunaan intonasi, 2) partikel interogatif, dan 3) tag interogatif. Persamaan bentuk konstruksi interogatif polar bahasa Jepang dan Indonesia terdapat pada aspek intonasi sebagai hal utama dalam pembentukan konstruksi interogatif polar, penggunaan partikel interogatif dan penggunaan tag Interogatif dalam kedua bahasa. Perbedaan konstruksi interogatif polar terletak pada penggunaan katatanya "apa”, "apakah" dan "bagaimana" yang lebih produktif dalam bahasa Indonesia dan partikel interogatif ka yang lebih produktif sebagai penanda interogatif polar dalam bahasa Jepang. Dalam kesepadanan penerjemahan umumnya partikel interogatif ka bahasaJepang disepadankan dengan katatanya "apakah" dalam konstruksi interogatif polar bahasa Indoesia.
\end{abstract}

Kata K unci: kontrastif, konstruksi interogatif, polar interogatif, bahasaJepang, bahasa Indonesia

\begin{abstract}
This research discusses about interrogativeconstruction of polar in J apaneseand Indonesian language. The purpose of this research describes theforms, similarities and differ ences, and the correspondence of interogative constructions in Indonesian and J apanese. Sources of data arerelated literature on inter rogativeconstructions and Indonesian and Japanesegrammar books. $D$ ata collection using techniques of refering and noting.Contrastive analysis is used to analyze data. The hestudy found that theinter rogative contrastive polar in Japaneseand Indonesian languages wereformed from use of 1 ) intonation, 2) interrogative particles, and 3 ) interrogative tags. The interrogative constructions of Japanese and Indonesian polar interrelations are inherent in the intonation aspect as themain thing in theconstruction of polar interrogation, theuseof interrogativeparticles and the use of nterogativetags in both languages. The differencebetween polar interrogative constructions lies in the use of moreproductive" apa", "apakah" and "bagaimana" words in Indonesian and moreproductive interrogative particles in Japanese polar interrogative. In the correspondence of translations most of the interrogative particles of J apaneseare equated with thequestion 'apakah' in thepolar interrogativeconstructions of Indonesian.
\end{abstract}

Keywords: contrastive, interrogativeconstruction, interrogative polar, Japanese, Indonesian

\section{PENDAHULUAN}

Kalimat dikatakan sebagai satuan bahasa terkecil yang berupa klausa, yang dapat berdiri sendiri dan mengandung pikiran lengkap
(Putrayasa, 2017:41), memiliki peran penting dalam tujuan komunikasi. Peran tersebut yaitu tersampaikannya informasi dari pembicara hingga ke pendengar. Pemerolehan informasi 
dan penyampaian informasi dapat dilakukan melalui pertanyaan. Dalam kajian sintaksis bentuk pertanyaan itu berkaitan dengan perihal konstruksi interogatif.

Interogatif adalah kalimat yang mengandung intonasi interogatif dan pada umumnya mengandung makna pertanyaan, dalam ragam tulis biasanya ditandai oleh tanda tanya (?). Dalam bahasa Indonesia ditandai oleh "kah" dan sebagainya (Kridalaksana, 2001:148). Se jalan dengan itu Crystal (1997:201) juga menjelaskan interogatif adalah istilah yang digunakan dalam klasifikasi gramatikal tipe kalimat dan biasanya terlihat berbeda dengan deklaratif. Mengacu pada bentuk kata kerja atau jenis kalimat/ klausa yang biasanya digunakan dalam ekspresi pertanyaan. Kontruksi interogatif dapat dibagi menjadi tiga, ada yang disebut interogatif polar (polar question), konten interogatif (content question) dan alternatif interogatif (Siemund, 2001:2).

Interogatif polar atau juga disebut dengan interogatif tertutup (Tarmini, 2009:80), merupakan konstruksi interogatif yang tujuan utamanya adalah mengajukan pertanyaan untuk dijawab "ya" atau "tidak" (Matthews, 2007:307). Siemund (2001:4) menyatakan untuk menandai konstruksi interogatif polar dalam berbagai bahasa dapat dilihat dari enam hal. pertama penggunaan intonasi, kedua partikel interogatif, ketiga tag interogatif, keempat disjungsi, kelima perubahan urutan konstituen (order of constituents) dan keenam infleksi verbal.

Intonasi merupakan ciri yang membedakan antara kalimat dengan klausa secara mutlak. Sunaryati seperti yang dikutip oleh Rahardi (2006) berpendapat bahwa intonasi adalah tinggi-rendah suara, panjang-pendek suara, keras-lemah suara, jeda, irama, dan timbreyang menyertai tuturan. Menurut Sunaryati, intonasi dapat dibedakan menjadi dua, yaitu intonasi yang menandai berakhirnya suatu kalimat atau intonasi final dan intonasi yang berada di tengah kalimat atau intonasi nonfinal (Rahardi, 2006:123).
Kentjono seperti yang dikutip oleh Suwiryo (2008: 39) berpendapat bahwa intonasi final dianggap memiliki peranan penting dalam penentuan status kalimat karena intonasi final inilah kalimat merupakan satuan gramatikal bebas. Dalam bahasa tulis, intonasi final ditandai dengan adanya tanda titik, tanda tanya, atau tanda seru yang merupakan batas antara kalimat yang satu dengan yang lain.

Partikel merupakan sebuah penegas apabila diikuti atau mengikuti kata lainya. Kata yang beriringan dengan partikel biasanya digunakan untuk menegaskan suatu pernyataan. Bentuk dari partikel sangatlah ringkas dan singkat, serta memiliki fungsi sebagai penampil unsur yang diiringinya. Dalam bahasa Jepang partikel disebut dengan joshi, yang terbagi menjadi empat jenis yakni (1) kakujoshi joshi, partikel yang dipakai setelah kata benda untuk menunjukkan hubungan antara kata benda tersebut dengan kata lainnya. Partikel yang termasuk kelompok ini misalnya ga, no, o, ni, e, to, yori, kara, de, dan ya. (2) Setsuzokujoshi joshi yaitu partikel untuk melanjutkan kata-kata yang ada sebelumnya terhadap kata-kata yang ada pada bagian berikutnya. Partikel yang termasuk keIompok ini misalnya ba, to, keredo, keredomo, ga, kara, shi, temo (demo), te (de) dan sebagainya. (3) Fukujoshi joshi yaitu partikel yang dipakai setelah berbagai macam kata. Partikel yang termasuk kelompok ini misalnya wa, mo, koso, sae, demo, shika, made, bakari, dake, hodo, kurai (gurai), nado, nari, yara dan sebagainya. Terakhir (4) shuujoshi yaitu partikel yang berada pada akhir kalimat untuk menyatakan suatu pertanyaan, seruan, larangan, dan sebagainya. Joshi yang termasuk kelompok ini misalnya ka, kashira, na, naa, zo, tomo, yo, ne, wa, no dan sebagainya. (Sudjianto dalam Ulwiyah, 2017:2)

Di dalam bahasa Jepang, kalimat tanya umumnya menggunakan pemarkah gramatikal berupa partikel interogatif ka atau variasinya, no desu + ka (Iori dalam Filia, 2012:4). Se hingga secara umum konstruksi introgatif polar juga dapat terbentuk hanya dengan menam- 
bahkan partikel interogatif ka (KO) pada akhir sebuah kalimat dan tidak perlu menggunakan tanda tanya. Susunan pertanyaan dalam bahasa Jepang tidak terlalu memerdulikan urutan kata. (Jonathan \& Tadaki, 2013:58) contohnya:

(1) あなたはインドネシア人です。

Anata wa indonesia jin desu.

Anda orang Indonesia

(2) あなたはインドネシア人ですか。

Anata wa Indonesia jin desu ka.

Anda orang Indonesia?

Konstruksi (1) adalah konstruksi deklaratif sementara konstruksi (2) adalah konntruksi interogatif polar. Dari contoh kalimat di atas terlihat bahwa hanya dengan menambahkan partikel ka diakhir konstruksi kalimat, akan mengubah konstruksi yang bermula konstruksi deklaratif menjadi konstruksi interogatif polar. Selain partikel ka dalam bahasa Jepang juga terdapat partikel interogatif yang digunakan dalam ragam bahasa lisan yaitu partikel ne, no, kai, yone, dane dan dai.

Tag interogatif merupakan bentuk konstruksi interogatif yang polanya menggunakan kata tanya di akhir kalimat, yaitu apabila dibuat suatu pernyataan dan mengakhirinya dengan pertanyaan agar pendengar memberikan penegasannya, disebut question tag. Konstruksi interogatif ini biasanya tidak membutuhkan jawaban karena digunakan untuk menanyakan hal-hal yang diyakini benar oleh penanya. Umumnya sering digunakan dalam bahasa lisan. Pembentukan question tag dapat terbentuk dengan rumusan jika konstruksinya positif maka question tag-nya negatif. Dalam konstruksi interogatif polar bahasa Jepang juga sering ditemukan dalam bentuk tag interogatif dengan penambahan kata jyanai (じゃない) yang berarti 'bukan' di akhir konstruksi. Kata jyanai merupakan bentuk menyangkal yang digunakan dalam tulisan resmi dan bahasa lisan yang tidak formal (seperti terhadap teman sebaya) (Sutedi, 2011:58; Pasaribu, 2013:12).
Disjungsi merupakan hubungan antara bagian konstruksi yang dipisahkan oleh atau dan tetapi yang menunjukkan kontras atau asosiasi, misalnya mereka miskin, tetapi selalu gembira (KBBI daring). Konstruksi interogatif polar dengan disjungtif terjadi dalam bahasa Mandarin dimana disjungsi klausa afirmatif dan mitranya yang negatif, yang disebut konstruksi A-not-A. (Siemund, 2001:10)

Perubahan urutan konstituen merupakan penanda kontruksi interogatif yang juga disebut dengan inversi, yaitu pembalikan susunan bagian kalimat yang berbeda dari susunan yang lazim. Kemudian infleksi verbal, yaitu pembentukan interogatif polar dengan adanya perubahan morfologi verbal yang khusus untuk membentuk konstruksi interogatif.

Kontruksi interogatif polar, disebut juga dengan kalimat tanya tertutup, tentu dimiliki semua bahasa di dunia, tapi terdapat perbedaan bentuk konstruksi interogatif polar dari masing-masing bahasa yang ada, misal nya dalam bahasa Jepang dan bahasa Indonesia.

Bahasa Jepang adalah salah satu bahasa di Asia yang cukup pesat perkembangannya di dunia. Jumlah pembelajar bahasa Jepang di Indonesia mencapai 872.411, di bawah negara Cina yang menempati urutan pertama pembelajar bahasa Jepang sejumlah 1.046 .490 orang (Puspitasari, 2015). Sebagai bahasa yang berasal dari rumpun bahasa berbeda dengan bahasa Indoensia, bahasa Jepang tentu memiliki karakteristik tersendiri yang berbeda dengan bahasa Indonesia. Dari sistem penulisannya, bahasa Jepang memiliki 4 (empat) sistem penulisan yaitu; kanji (漢字), hiragana (ひらがな), katakana (カタカナ), dan romaji (ロマ字) (Yukari, 2015), kemudian dari konstruksi gramatikalnya juga berbeda dengan bahasa Indonesia, misalnya di dalam struktur frasa dalam bahasa Indonesia unsur inti (D) mendahului unsur bukan-inti (M). Sebaliknya pada frasa nominal bahasa Jepang unsur bukan-inti (M) yang mendahului unsur inti (D). (Soidi, 
2010:133). Contohnya pada kata nihongo no hon.

$\begin{array}{ll}\text { (3) } \frac{\mathrm{N} \text { ihongo }}{\mathrm{Z}} & \frac{\mathrm{H} \text { on }}{\mathrm{Z}} \\ \begin{array}{ll}\text { (M) } & \text { (D) }\end{array}\end{array}$

Bahasa Jepang Buku

Artinya: buku bahasa Jepang

Dilihat dari fungsi sintaktisnya, konstruksi bahasa Jepang berpola SOP (Subjek-ObjekPredikat) (Sutedi, 2011:66), berbeda dengan konstruksi bahasa Indoenesia yang berpola SPO (Subjek - Predikat - Objek). Contohnya:

(4) Watashi wa zasshi o yomimasu

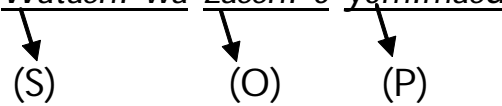

Saya majalah membaca

Artinya: Saya membaca majalah

Perbedaan ini tentu juga akan berkaitan dengan perbedaan kontruksi interogatif polar dari bahasa Jepang ke bahasa Indonesia. Konstruksi interogatif di dalam bahasa Jepang disebut dengan gimonbun ( 疑問文). Pada umumnya konstruksi interogatif dalam bahasa Jepang ditandai dengan partikel interogatif akhir kalimat ka (か). Partikel interogatif ka memiliki peran penting dan hampir selalu ada dalam konstruksi interogatif dalam bahasa Jepang, karena partikel interogatif ka sama halnya dengan penanda interogatif (?) yang lazim digunakan dalam bahasa Indonesia sebagai penanda interogatif. Selain itu, penentu konstruksi interogatif dalam bahasa Jepang tentunya dapat dilihat ada aspek lainnya.

Berdasarkan fakta di atas, menarik untuk dikaji bagaimana kontrastif pada konstruksi interogatif bahasa Jepang dan bahasa Indonesia. Oleh karena itu, dalam penelitian ini akan dibahas beberapa hal berkaitan dengan kontrastif konstruksi interogatif polar dalam bahasa Jepang dan Indonesia. Pertama, bagaimana bentuk dan kaidah konstruksi interogatif polar antara bahasa Jepang dan bahasa Indonesia. Kedua, bagaimana persamaan dan perbedaan konstruksi interogatif antara bahasa
Jepang dan bahasa Indonesia. Ketiga, bagaimana kesepadanan konstruksi interogatif dalam bahasa Indonesia dan bahasa Jepang dalam penerjemahan.

\section{TEORI DAN METODE}

Teori analisis kontrastif yang digunakan adalah menurut Tarigan (2009) bahwa analisis kontrastif adalah kegiatan membandingkan dua struktur (B1 dan B2) yang berbeda untuk mengidentifikasi perbedaan antara dua bahasa yang berasal dari rumpun yang berbeda. SeIanjutnya Tarigan mengatakan bahwa hambatan terbesar dalam menguasai bahasa kedua (B2) adalah tercampurnya sistem bahasa pertama (B1) dengan sistem B2. A nalisis kontrastif mencoba menjembatani kesulitan tersebut dengan mengkontraskan kedua sistem bahasa tersebut untuk menentukan kesulitan-kesulitan yang terjadi.

Penelitian ini merupakan penelitian kontrastif dengan metode kualitatif deskriptif. Me nurut Moleong (dalam Gapur, 2017:216) pendekatan kualitatif menekankan pada proses, sehingga penelusuran data dan informasi secara diakronik akan dilakukan untuk mengetahui dan memahami secara runtut dan lengkap. Mengingat esensi metode kualitatif dalam memandang masyarakat sebagai subjek, berdasarkan pandangan masyarakat itu data yang didapat benar-benar seperti adanya. Analisis kontrastif dalam penelitian ini terdiri dari empat tahapan. Pertama, memasangkan data untuk menunjukkan sesuatu yang relevan dalam masing-masing bahasa yang dibandingkan. Kedua, menyatakan realisasi dari setiap kategori gramatikal yang berkaitan dengan analisis kontrastif yang sedang dilakukan untuk masing-masing bahasa. Ketiga, menyediakan data. Keempat, menentukan perbedaan yang telah diidentifikasi dengan langkah kedua dan ketiga.

Dalam penelitian ini yang menjadi objek penelitian adalah kontruksi interogatif baik dalam bahasa Indonesia maupun dalam ba- 
hasa Jepang. Data penelitian diambil dari sumber tertulis, berupa klausa atau kalimat yang benar-benar mengandung aspek interogatif polar dalam bahasa Indonesia dan bahasa Jepang. Sumber tertulis tersebut diperoleh dari literatur berupa buku dan hasil penelitian berkaitan dengan kontsruksi interogatif dalam bahasa Indonesia dan bahasa Jepang. Selain itu, data penelitian juga diambil dari buku pelajaran bahasa Jepang M inna no nihongo shokyuu I dan $\mathrm{N}$ ameraka nihongo kaiwa. Buku ini dipilih karena mewakili literatur yang sering digunakan dalam pembelajaran bahasa Jepang. Buku M inna no $\mathrm{N}$ ihongo shokyuu I berisikan bentuk-bentuk kalimat formal sementara buku $\mathrm{N}$ ameraka $\mathrm{N}$ ihongo kaiwa berisikan kalimat-kalimat percakapan dalam bentuk nonformal. Dengan begitu data kontruksi interogatif polar yang didapati akan mencakup berbagai situasi percakapan.

Penelitian ini dilakukan dalam tiga tahap, yaitu (1) penyediaan data, (2) analisis data, dan (3) penyajian hasil analisis data (Sudaryanto, 2015: 6-8). Ketiga tahap tersebut dilakukan dengan metodedan teknik tersendiri. Penyediaan data dari sumber tertulis dilakukan dengan metodesimak dan dilanjutkan dengan teknik catat (Sudaryanto, 2015:133-136). Metode simak adalah metode yang dilakukan dengan menyimak penggunaan bahasa secara tertulis yang dilanjutkan dengan mencatat data yang diperlukan.

Untuk mengkaji konstruksi introgatif bahasa Indonesia dan Jepang, akan digunakan metode analisis kontrastif. M etode tersebut dilakukan dengan cara membandingkan konstruksi interogatif dalam bahasa Indonesia dan bahasa Jepang melalui pendekatan linguistik strukturalis. Setelah diperbandingkan, kemudian dicari perbedaan dan persamaan di antara kedua bahasa. Dalam menganalisis konstruksi interogatif kedua bahasa secara umum digunakan teori Siemund (2001), kemudian dalam menganalisis ciri-ciri konsrtuksi interogatif bahasa Indonesia digunakan beberapa teori sebagai acuan, seperti teori Alwi dkk (2003), Putrayasa (2017) dan Effendi, Dr., dkk (2015). Teori Sutedi (2011) dan Santoso (2015) digunakan untuk menjelaskan mengapa terdapat perbedaan di bidang sintaksis khususnya konstruksi interogatif antara bahasa Indonesia dan bahasa Jepang.

Metode penyajian hasil analisis dalam penelitian ini menggunakan metode penyajian informal. Metode penyajian informal adalah merumusan dengan kata-kata biasa, walaupun dengan terminologi yang sifatnya teknis (Sudaryanto, 2015:145).

\section{HASIL DAN PEMBAHASAN}

Pada hasil kajian kontrastif polar interogatif bahasa Jepang dan bahasa Indoonesia ditemukan bahwa bentuk dan kaidah konstruksi interogatif polar bahasa Jepang tidak memiliki kata tanya, tapi lebih besar dipengaruhi oleh partikel interogatif akhir kalimat (Joshi), intonasi interogatif, dan tag interogatif.

Sementara di dalam konstruksi interogatif polar bahasa Indonesia terbentuk dengan intonasi interogatif, partikel interogatif, dan kata tanya serta taq interogatif.

Persamaan bentuk konstruksi interogatif polar bahasa Jepang dan Indonesia terdapat pada aspek intonasi sebagai hal utama dalam pembentukan konstruksi interogatif polar, penggunaan partikel interogatif dalam membentuk konstruksi introgatif, dan penggunaan tag Interogatif dalam kedua bahasa.

Perbedaan konstruksi interogatif polar antara bahasa Jepang dan Indonesia terdapat dalam produktifitas penggunaan partikel interogatif, dimana dalam bahasa Jepang partikel interogatif akhir lebih produktif digunakan dibandingkan bahasa Indonesia. Partikel interogatif di dalam bahasa Jepang berada di akhir konstruksi. Berbeda dengan partikel interogatif bahasa Indonesia yang dapat menempati awal konstruksi mengikuti satuan konstituen. Kemudian di dalam konstruksi interogatif polar bahasa Jepang tidak dapat dibentuk degan kata 
tanya, namun di dalam bahasa Indonesia konstruksi interogatif polar dapat dibentuk dengan kata tanya "apa, apakah dan bagaimana"

\section{Bentuk dan Kaidah Konstruksi Intero- gatif Polar antara Bahasa Jepang dan Ba- hasa Indonesia}

\section{a. Penggunaan Partikel Interogatif}

Partikel interogatif adalah salah satu aspek penting dalam pembentukan konstruksi interogatif polar Bahasa Jepang. Terdapat beberapa macam partikel interogatif di dalam bahasa Jepang, seperti ka, kai, ne, yone, no dan dai. Berikut beberapa contoh konstruksi interogatif polar yang ditemukan.

(5)これはテレホンカードですか

Kore wa terehonkaado desu ka

Ini kartu telepon?

(Nettowaku, 2008: 14)

(6) おいしいワインですね?

Oishii wain desu ne?

Wain enak ya?

(N ettowaku, 2008: 198)

（7）ねえ、あなたまだ寝ないの？

$\mathrm{Nee}$, anata mada nenai no?

Eh, kamu belum tidur?

(Tomisaka, 1997:)

（8）今日も学校があるのかい？

Kyou mo gakkou ga aru no kai?

Hari ini ada sekolah?

(Tomisaka, 1997:86)

（9）明日雨降ったら、運動会中止だよね? A shita ame futtara, undoukaichuushi da yone? Kalau besok turun hujan, festival olahraga berhenti ya?

(Tomisaka, 1997: 96)

(10)クラブに入りたんだい?

kurabu ni haritann dai?

Masuk keklub?

(Tomisaka, 1997:103)
Kontruksi interogatif polar pada (5) sampai dengan (10) menggunakan partikel akhir kalimat sebagai penanda interogatif. Partikel tersebut yaitu partikel ka, ne, no, kai, yone dan dai. Hal ini sesuai dengan pendapat Siemund (2011) bahwa salah satu penanda interogatif dalam suatu bahasa adalah penggunaan partikel interogatif. Variasi partikel dalam konstruksi bahasa Jepang di atas partikel ka, ne, no, kai, yone, dan dai yang digunakan dalam konstruksi menjadi pemarkah yang membentuk konstruksi interogatif polar.

Selanjutnya jika dibandingkan dengan konstruksi interogatif polar bahasa Indonesia, terdapat partikel interogatif "kah" yang tidak produktif dan posisinya tidak selalu ada di akhir konstruksi. Berikut beberapa contoh konstruksi interogatif polar bahasa Indonesia.

(11)Mereka bercerai (kah)?

(12)A nak itu bermain (kah)?

(13)Pacarnnya seorang dokter (kah) ?

(14)Bajunya baru (kah) ?

(15)Benar(kah) dia datang ?

(16)Setuju(kah) dia?

(Putrayasa, 2011)

Seluruh konstruksi di atas menunjukkan bahwa keberadaan partikel "kah" tidak menjadi penentu pembentukan konstruksi interogatif polar. Karena tanpa ada penambahan partikel "kah" konstruksi diatas tetap dapat membentuk konstruksi interogatif polar dengan penggunaan intonasi. sehingga dapat dikatakan partikel interogatif dalam konstruksi interogatif polar bahasa Indonesia dalam contoh di atas tidak produktif. Kemudian konstruksi (15) dan (16) menunjukkan bahwa posisi partikel interogatif tidak selalu berada di akhir konstruksi seperti bahasa Jepang namun juga bisa berada di tengah konstruksi.

\section{b. Kata Tanya dalam Konstruksi Interogatif Polar}

Dalam konstruksi interogatif polar Jepang tidak ditemukan kata tanya. Hal ini karena 
fungsi partikel tanya dapat bersepadan dengan makna kata tanya introgatif polar dalam bahasa Indonesia. Misalnya konstruksi berikut. (17)これはテレホンカードですか

(Nettowaku, 2008: 14)

Kore wa terehonkaado desu ka

(Apakah) ini kartu telepon?

Kata "apakah" sebenarnya tidak terdapat dalam konstruksi (17). Namun penggunaan partikel ka (か) dapat memberi kesepadanan makna dengan kata tanya "apakah" di dalam bahasa Indonesia.

Kata tanya dalam kontruksi interogatif polar bahasa Indonesia terdapat tiga kata, yaitu kata tanya apa, apakah, dan bagaimana. Letak urutan kata tanya di dalam konstruksi interogatif cenderung menempati posisi di depan atau di awal kalimat.

Kata tanya dalam konstruksi interogatif polar bahasa Indonesia tidak mengisi atau menggantikan fungsi sintaksis. Oleh karena itu, pelesapan kata tanya dengan intonasi tertentu dapat dilakukan tanpa mengubah informasi yang ditanyakan.

Contoh analisis penggunaan kata tanya dalam konstruksi interogatif polar dapat dilihat pada paparan berikut ini.

(18)A pa saya salah?

(S)

\section{..... saya salah?}

Saya salah, apa ? (dengan intonasi tertentu dapat membentuk interogatif polar)

(19)A pa selama ini saya memberi harapan?
(Ket)
(S)
(P)
(O)

... selama ini saya memberi harapan?

Selama ini apa saya memberi harapan?

Selama ini saya memberi harapan, apa ?

(20) Apakah kamu bisa menemui dia juga?

(S)

(P)

(Pel)
(21)A pa perlu kupanggilkan Darsam ?

.... perlu kupanggilkan Darsam ? Kupanggilkan Darsam apa perlu?

Pada konstruksi (18), (19), dan (20) kata tanya sebagai konstituen kata berkorelasi de ngan kategori sintaktis berupa konstruksi saya salah, konstruksi selama ini saya memberi harapan, dan konstruksi kamu bisa menemui dia juga. Kata tanya sebagai konstituen kata memiliki letak urutan yang tidak terikat, sehingga letak urutan di dalam kalimat bisa dipindahkan, kecuali untuk kata tanya apakah yang tidak dapat menempati posisi di akhir kalimat. Pada konstruksi (21) kata tanya apa berbentuk sebagai konstituen frasa yang berkorelasi dengan kategori sintaktis frasa verba "kupanggilkan Darsam". Informasi yang disampaikan pada konstruksi (18) berupa informasi baru, sedangkan informasi yang disampaikan pada konstruksi (19), (20), dan (21) berupa informasi lama. Pada konstruksi (19) informasi lama secara eksplisit ditandai oleh konstituen frasa adverbia "selama ini", sedangkan pada konstruksi (20) dan (21) informasi lama ditandai oleh konteks konstruksi yang merujuk pada kejadian sebelumnya.

Kemudian penggunaan kata tanya bagaimana dalam konstruksi polar interogatif dapat dilihat pada contoh kalimat (22) berikut ini.

(22)Bagaimana, setuju?

...... setuju ?

Kata tanya "bagaimana" pada konstruksi (20) secara leksikal digunakan untuk menanyakan keadaan dengan jawaban yang diharapkan berupa informasi tertentu. Pemakaian kata tanya "bagaimana" dalam konstruksi polar interogatif bahasa Indonesia pada dasarnya terjadi karena adanya pelesapan kata tanya "apa" atau "apakah" sebagai alat polar interogatif, sehingga konstruksi (20) berasal dari konstruksi interogatif sebagai berikut.

kamu bisa menemui dia juga?

Kamu apakah bisa menemui dia juga?

*Kamu bisa menemui dia juga, apakah ? 
(20a)Bagaimana, $\left|\begin{array}{c}\varnothing \\ \text { apa } \\ \text { apakah }\end{array}\right|$ setuju?

\section{c. Intonasi dalam Konstruksi Interogatif Polar Bahasa Jepang dan Indonesia.}

Selain partikel interogatif, intonasi juga sangat berperan penting dalam pembentukan konstruksi interogatif polar bahasa Jepang dan Indonesia. Berikut beberapa contoh konstruksi yang menunjukkan hal tersebut.

Bahasa Jepang :

\section{(21)そこにはさみがある？}

(Nettowaku, 2008:164)

Soko ni hasami ga aru?

Di sana ada gunting?

(22)鈴木さん、今忙しい?

(Tomisaka, 1997:92)

Suzuki san, ima isogashii?

Suzuki, sekarang seibuk?

Bahasa Indonesia :

(23)Anak nya tujuh orang?

(24)Tabungannya sepuluh juta?

Pada kontruksi interogatif polar bahasa Indonesia dan Jepang di atas terlihat bahwa konstruksi hanya dibentuk dengan menggunakan intonasi sebagai penanda interogatifnya. Dalam ragam tulis bahasa Indonesia konstruksi interogatif dengan intonasi menggunakan penanda interogatif berupa tanda tanya (?). $\mathrm{Hal}$ ini sesuai dengan pendapat Siemund (2011) bahwa salah satu penanda interogatif dalam suatu bahasa adalah penggunaan intonasi. Pada konstruksi interogatif di atas apabila tidak digunakan intonasi atau dalam ragam tulis ditandai dengan tanda (?), maka kalimat tersebut tidak akan diketahui sebagai konstruksi interogatif.

\section{d. Tag Interogatif dalam Konstruksi Intero- gatif Polar Bahasa Jepang dan Indonesia.}

(25)通勤が不便になるじゃないか

(Tomisaka, 1997:27)

Tsuukin ga fuben ni naru jyanai ka

tidak praktis komuternya bukan?

(26)会社でパソコン使ってるんじゃないの?

(Tomisaka, 1997:36)

Kaisha de pasokon tsukatterun jyanai no?

Menggunakan komputer di kantor bukan?

Kontruksi interogatif polar (25) dan (26) di atas dibentuk dengan tag interogatif kata jyanai yang berati "bukan". Kata jyanai diletakkan di akhir kalimat sebagai pertanyaan singkat mengikuti konstruksi sebelumnya. Pada dua konstruksi di atas, kata jyanai dipertegas juga dengan partikel intererogatif ka dan no sehingga semakin menunjukkan bahwa kontruksi tersebut merupakan konstruksi interogatif. $\mathrm{Hal}$ ini juga sesuai dengan pendapat Siemund (2011) bahwa salah satu penanda interogatif dalam suatu bahasa adalah adanya tag interogatif. Dari konstruksi di atas juga diketahui bahwa tag interogatif dalam bahasa Jepang berbentuk tag interogatif negatif.

Tag interogatif bahasa Indonesia juga sama dengan tag interogatif polar bahasa Jepang, yaitu berbentuk tag interogatif negatif. Digunakan bentuk negatif "tidak", "bukan" dan "-kan" (sebagai singkatan dari kata "bukan"). Misalnya dalam contoh konstruksi berikut.

(27)Saya hebat, iya tidak/ (bu)kan?

(28)Kamu tidak ingin camput tangan, (bu)kan?

(Efendi dkk, 2015)

\section{PENUTUP}

Kontrastif polar interogatif bahasa Jepang dan bahasa Indoonesia terbentuk dari 1) penggunaan intonasi, 2) partikel interogatif, dan 3) tag interogatif. Persamaan bentuk konstruksi interogatif polar bahasa Jepang dan Indonesia terdapat pada aspek intonasi sebagai hal 
utama dalam pembentukan konstruksi interogatif polar, penggunaan partikel interogatif dalam membentuk konstruksi introgatif, dan penggunaan tag Interogatif dalam kedua bahasa.

Perbedaan konstruksi interogatif polar bahasa Jepang dengan bahasa Indonesia terletak pada penggunaan kata tanya dan partikel interogatif. Konstruksi interogatif bahasa Jepang tidak memiliki kata tanya, tapi lebih be sar dipengaruhi oleh partikel interogatif akhir konstruksi (Joshi), intonasi interogatif, dan urutan konstituen yang membentuk konstruksi interogatif. Sementara di dalam konstruksi interogatif polar bahasa Indonesia terdapat partikel interogatif dan kata tanya "apa" atau "apakah" yang produktif dalam membentuk konstruksi interogatif. Kemudian partikel interogatif bahasa Indonesia dapat menempati awal konstruksi mengukiti satuan konstituen.

Dalam kesepadanan penerjemahan umumnya partikel interogatif ka bahasa Jepang dise padankan dengan kata tanya "apakah" dalam konstruksi interogatif polar bahasa Indonesia.

\section{DAFTAR PUSTAKA}

Alwi, Hasan, dkk. (2003). Tata Bahasa Baku Bahasa Indonesia (edisi ketiga). Jakarta: Balai Pustaka.

Crystal, David. (1997). A dictionary of linguistics and phonetics 4th edition. Cambridge, MA: Blackwell.

Effendi, dkk. (2015). Tata Bahasa Dasar Bahasa Indonesia. Bandung: Remaja Rosdakarya.

Filia. (2012). Pertanyaan dan Respons Bahasa Jepang pada Tayang Bincang Asaichi. Prosiding Seminar Internasional Pendidikan Bahasa Jepang. Bali

Gapur, Abdul. 2017. U paya pengurangan Interferensi Gramatikal Bahasa Indonesia dalam Pembelajaran Bahasa Jepang. Jurnal Kebahasaan dan Kesastraan Genta Bahtera Vol. 3, No. 2, Desember 2017
Jonathan \& Tadaki, Chiba. (2013). Japanese Grammar Pool Kumpulan Tata Bahasa Jepang. Malang : Linguistic Pool Media.

Kridalaksana, Harimurti. (2001). Kamus Linguistik Edisi ketiga. Jakarta : PT. Gramedia Pustaka Utama.

Matthews, Peter Hugoe. (2007). The Concise 0 k87xford Dictionary of Linguistics Second Edition. Oxford: Oxford University Press.

Nettowaku, 3A. (2008). M inna N o N ihongo Shokyu I, Indonesian V ersion. Surabaya: IMA Foundation Press.

Pasaribu, Parlindugan. (2013). Analisis Penggunaan $\mathrm{H}$ iteikei $\mathrm{H}$ yougen ( $\mathrm{N}$ akerebanaranai, $\mathrm{N}$ akutew an aranai, N aitoikenai). Skripsi Universitas Negeri Semarag (online). http:/ /lib.unnes.ac.id/18185/1/2302909027.pdf (dilihat tanggal 11 Desember 2017)

Puspitasari, Siska Nirmala. (26/ 102015). Indonesia Peringkat Kedua D unia Pembelajar Bahasa Jepang Terbanyak. Portal berita online Pikiran Rakyat. diakses tanggal 19 Sepetember 2017, dari http://www. pikiranrakyat.com/pendidikan/2015/10/26/347501/ indonesia-peringkat-kedua-du nia-pembelajarbahasa-jepan g-terbanyak

Putrayasa, I. B. (2017). Sintaksis (M emahami Kalimat Tunggal). Bandung: Refika A ditama.

Rahardi, R. Kunjana. (2006). Pragmatik: Kesantunan Imperatif Bahasa Indonesia. Jakarta: Penerbit Erlangga.

Santoso, Teguh. (2015). Kajian Linguistik Kontrastif Tingkatan Bahasa Jepang dan Bahasa Jawa.Y ogyakarta : Morfalingua.

Siemund, Peter. (2001). Interrogative constructions. In Language Typology and Language Universals, Vol. 2, Martin Haspelmath, Ekkehard Konig, wulf Oesterreicher and Wolfgang Raible (eds), 1010-1028. Berlin: de Gruyter.

Soidi, Orestis. (2010). Perbandingan Konstruksi Frasa Bahasa Jepang Dan Bahasa Indonesia Serta Implikasinya Pada Pengajaran D okkai 
$D$ an $H$ on'yaku. Jurnal Interlingua FBS UNIMA Vol 4 A pril 2010 (online)

Sudaryanto. (2015). M etode dan A neka Teknik A nalisis Bahasa Pengantar Penelitian W ahanan

Kebudayaan Secara Linguistik. Yogyakarta: Sanata Dharma University Press.

Sutedi, Dedi. (2011). Dasar-dasar Linguistik Bahasa Jepang Edisi Revisi. Bandung : Humaniora Utama Press.

Suwiryo, Adhika Irlang. (2008). Tuturan Bermakna Perintah Berdasarkan Intonasi Imperatif, D eklaratif, Dan Interogatif D alam Komedi Situasi O ffice Boy. Skripsi Universitas Indonesia (Tidak Dipublikasi)

Tarigan, Henry Guntur. (2009). Pengajaran A nalisis Kesalahan Berbahasa. Bandung: Angkasa
Tarmini, Wini. (2009). Kata Tanya dalam Konstruksi linterogatif Bahasa Indonesia: Kajian Sintaksis dan Semantis. Bandung: Jurnal sosiohumaniora. Vol 11, No 1 (2009) Hal. 77 -92 diambil dari http:// jurnal.unpad.ac.id/sosi ohumaniora/article/ view/5580/2941 (19 September 2017)

Tomisaka, Yoko. (1997). j0 %o0K0åe,gžŠ OqŠ Successful Communication in Japanese. Tokyou: $\$ 0 \ddot{0} 0^{-} 0$.

Ulwiyah, Luluk. (2017). Keefektifan Penggunaan I con Dalam Penguasaan Partikel De pada Kalimat Bahasa Jepang. Skripsi U niversitas M uhammadiyah Yogjakarta (online). http:// repository.umy.ac.id/handle/123456789/ 10746 (dilihat tanggal 10 Desember 2017). 